\title{
Analysis of the Character of Students in Learning Civic Education Based on High Order Thinking Skills
}

\author{
Umi Chotimah $^{1}$, Kurnisar ${ }^{2}$, Ermanovida $^{3}$, Norma Juainah ${ }^{4}$ \\ ${ }^{1}$ Civic Education, Sriwijaya University \\ ${ }^{2}$ Civic Education, Sriwijaya University \\ ${ }^{3}$ Public Administration, Sriwijaya University \\ ${ }^{4}$ Public Administration, Sriwijaya University \\ ${ }^{*}$ Corresponding author. umichotimah@unsri.ac.id ${ }^{l}$,
}

\begin{abstract}
There is no limit to character building, including for students in universities, because students are the younger generation who are educated to become intellectuals to support national development. Civics Education is one of the personality development courses (MPK), and students in tertiary institutions in Indonesia must have more responsibility in terms of character education because one of the ultimate goals is to become citizens with intelligent character, upholding human, moral values. -ethics, religion, justice, and others. This study aims to analyze the character values of students through HOTS-based Civics learning. The implementation is carried out in the first semester of Civics learning, using a qualitative approach, and with the main informant consisting of five students. Data were collected using observation, interview, and documentation techniques. The validity of the data was tested through credibility, transferability, dependability, confirmability tests. Furthermore, the data were tested qualitatively, namely through data reduction, data presentation, and conclusion drawing. Based on the results of data analysis and discussion, it can be concluded that in terms of achieving the Civics course's learning objectives, everything has been achieved. However, if viewed from the number of character values that appear, it can be concluded that most of the values in character education appear, but some are dominant. There is less dominant. The dominant character values that emerge include curiosity, responsibility, independence, love for the country, religion, democracy, and love for the country. Thus it is suggested that more diversity of HOTS-based learning models should be applied so that they can support more (dominant) attainment of character values.
\end{abstract}

Keywords: Character Buliding, Civic Edcucation study, HOTS, MPK

\section{INTRODUCTION}

Character education is based on teachers' methods and approaches as facilitators in the classroom. To carry out character development requires careful and precise preparation so that character values can be developed optimally $[1,2,16]$. Besides that, the environment and various other components should also build students' character, both from the family environment, peers, and various parties. Civic Education (Civics) has an essential role in building students' character, especially in the moral and ethical field of each individual. Therefore Pancasila and citizenship education is essential for the world of education . [7,9,15].

The learning activity is an activity that can be done to form and strengthen the character values that exist in students. Through HOTS (Higher Order Thinking Skills) based learning activities, character values' internalization tends to be more optimal due to a critical and in-depth mindset. [6] Education is the primary vehicle for developing good character. Human character is not born from birth but is the result of the formation or forging of the environment, including people around the environment. Character possessed by a person is formed through a long learning process. Character is formed through a learning process such as at home, school, and in the neighborhood. The parties who play an essential role in shaping a person's character are family, educators, and peers. Presidential Regulation Number 87 of 2017 Article 2 makes character education a national education platform to equip students as the "Golden Generation of 2045" with the spirit of Pancasila and good character.

In order to deal with the dynamics of change in the future. Referring to the Perpres, it means that character education receives essential attention from the government. Thus, the application of character education is limited to students at the primary and secondary education level and for students at the higher education level. In early 2020 with the existence of a new policy from the Ministry of Education and Culture regarding the concept of "Free Learning,." One of the concepts of independent learning in tertiary institutions is that a lecturer determined by the campus must guide students' activity. Regarding the two concepts above, of course, the problem of character and HOTSbased learning is still something that should not be ruled out. [11]. 
Character building on campuses, especially in universities (PT), is motivated by widespread deviations in the public sphere. Value disorientation and disharmony at the level of people's lives are often found. Besides, at the elite level, various exemplary acts are exhibited, such as corrupt behavior. Character education for students is essential to strengthening morals and commendable traits for students (in this case, students) because intelligence in education alone is not enough without strong moral and character provisions. When students enter the community, there will be no misuse of the knowledge learned during campus. From a social perspective, the shame culture is slowly disappearing. Not to mention the attitude of disrespect for others to the emergence of violence in people's lives. In student affairs, all relevant policymakers are faced with the problem of returning noble values to each student. Therefore, character-building wants to restore the paradigm of thinking. So that students are not only smart, knowledgeable, and superior, but also responsible and ethical. This is because the current education system is deemed insufficient to answer the nation's fundamental character-building problems. It is said that our education fails to form humans with great character. [8]

Given the importance of character, educational institutions, including universities, are responsible for instilling character through the learning process. (2) The importance of character education in tertiary institutions, following the Higher Education Curriculum, referred to in paragraph (1), is developed by each higher education institution regarding the National Higher Education Standards for each Study Program, including intellectual intelligence, noble character, and skills.[14]

Permenristekdikti No.44 of 2015 concerning National Education Standards Article 6 states that the attitude referred to in Article 5 paragraph (1) is correct and cultured behavior due to internalization and actualization of values and norms reflected in spiritual and social life through the learning process, work experience. Students, research, and community service related to learning. Furthermore, Article 10 paragraph (2) states that one of the characteristics of tertiary institutions' learning process is prioritizing the development of creativity, personality, and student needs and developing independence in seeking and finding knowledge. Based on this Permenristekdikti, it implies that learning carried out in higher education can develop the potential of students who are ultimately able to seek and develop knowledge independently. In connection with the learning process characteristics in tertiary institutions above, higher-order thinking skills should be required. This is because students are students who have been categorized as adult humans. A student is, of course, required to master abilities; one of the most critical abilities for students is the ability to think at a high level or known as High Order Thinking Skills (HOTS) because high-order thinking is one of the stages of thinking that cannot be separated from everyday life. Every student is directed to have high-order thinking patterns because higher-order thinking skills make someone think critically. [5]
An investigative type of learning style is a learning style that has characteristics, namely: thinking logically, analytically, critically, curiosity, and humility because this type of learning style is per higher-order thinking skills, where investigative students use their investigative skills in solving problems and prefer methods that use critical, logical and analytical thinking skills in solving the problems at hand. High-level thinking skills that include the ability to think at the level of analyzing, evaluating, and creating ideas are essential skills for the achievement of 21st-century competencies, consisting of critical, creative, collaborative, and communicative thinking skills indispensable for students' needs in solving. The problems it faces in everyday life. Civic Education or Civics is one of the compulsory courses in higher education in Indonesia. It means that Civics learning must also be carried out with various learning and assessment approaches and methods that allow students to think at higher levels. In other words, learning in higher education emphasizes the value of student character and higher-order thinking skills. Through character education, it is hoped that students will be able to independently improve and use their knowledge to study and internalize the values of character and noble morals to manifest in daily behavior. However, in reality, value orientation in student life is now shifting to be hedonistic and more egotistical. A brawl between two groups of students from the Faculty of Engineering, University of North Sumatra (USU), was involved in an attack on the local campus. The action was allegedly triggered by a banner problem [12]. Besides, there were also student brawls causing one person to die at HKBP Nommensen University (UHN), Medan, North Sumatra. The UHN rectorate stated that the perpetrators of vandalism and crimes must be dealt with [17]. In Makassar, students of Makassar State University (UNM) were involved in clashes. Students from two faculties, namely Language / Literature and the Faculty of Arts, were involved in brawls, and there are many examples of brawls that have caused victims and damaged the environment. Immoral acts, which have been rife recently, are concrete examples of shifting cultural values and social among students. In terms of students' high-order thinking skills, the average PISA results for SMP, SMA, and SMK National Examinations from 2016-2018 tend to decline. Another parameter is the PISA (Program for International Student Assessment) or the 2015 International Student Assessment Program conducted by the OECD (Organization for Economic Cooperation and Development), which measures the basic abilities of 15year-old students. It turns out that Indonesian students rank in the fields of mathematics, reading, and science. Still low. Mathematics scores 386 on 66, reading 397 on 67, and science 403 on 65 . Other data shows that Indonesia's percentage is based on the level of student ability at levels $<1,1,2,3,4,5$, and 6 , respectively. amounted to $42.3 \%$, $33.4 \%, 16.8 \%, 5.7 \%, 1.5 \%, 0.3 \%$, and $0.0 \%$. This data shows that students' high-level thinking skills are still low. This is also supported by the research results that the ability of students to think at the level of analysis, evaluation, and creativity, especially in secondary schools 
in Indonesia, is generally still low [3]. The issue of culture and character as the impact of the current exchange of information and the rapid distribution of information is due to the inadequate efforts to form students' character in our education system. In addition, the low level of highorder thinking besides. Indonesian students are generally students are not used to solving since earning. Based on data from the analysis of the 2015 TIMSS results, it shows that Indonesian students tend to master routine questions, simple computations, which emphasize the memory aspect and do not train students' higher-order thinking skills. This condition is also a result of current learning that focuses more on procedural skills, one-way communication, monotonous class arrangements, and low-order thinking skills (LOTS), which depend on textbooks and are more dominant in solving routine low-level questions. [5]. To be able to form character values and train students 'higher order thinking skills, it takes the efforts of higher-ordering this case lecturers) to be able to design learning activities that contain teaching materials, media and even evaluation tools in learning based on students' higher-order thinking skills, but on the other hand, it remains to pay attention to the importance of character education in it. Previous research has revealed that ICT-based learning can support students 'high-order thinking skills [5]. Conducted a study on students' high-order thinking skills through the application of learning models and conducted studies on character values through the application of models learning. In contrast to the primary and secondary education levels, research related to HOTS-based learning and the development of character values at the tertiary level, especially those related to student activities outside of learning hours (extracurricular activities), is still categorized as minimal, primarily related to Civics learning as one of the compulsory subjects for all students from all faculties at Sriwijaya University (Unsri). Including the relatively rare research on Civics at Technical Implementation Unit (UPT) Personality Development Course (Matakuliah Pengembangan Kepribadian (MPK). Besides, research related to new character values is limited to developing character valuebased learning tools and assessment instruments without further analyzing the character values of students that appear in the learning process. Therefore, considering the limitations of previous research, this study was intended to be conducted to analyze students' character values in HOTS-based Civics learning at UPT-MPK Sriwijaya University.

\section{METHOD}

This research was conducted using a descriptive qualitative approach using the case study method, which aims to describe the character values of students that emerged during HOTS-based Civics learning in the Technical Implementation Unit (UPT) of the Sriwijaya University Personality Subject Development Course, which was carried out in odd semester 2020/2021 academic year.

\section{RESULT AND DISCUSSION}

Citizenship education functions as a vehicle for forming intelligent, skilled, character, and loyal citizens to the Indonesian nation and state with Pancasila's habits of thought and action and the 1945 constitution. The function of Citizenship education is a place to form intelligent citizens., skilled, and faithful who are loyal to the nation and state of Indonesia by reflecting on habits of thinking and acting according to needs. [3, 10]

Based on the above opinion, the researcher can conclude that the function of citizenship education subjects is a place that can form smart, skilled, and fair character citizens so that they have the habit of thinking and acting with Pancasila and the 1945 constitution. The objectives of citizenship education include (1) critical thinking on citizenship issues, (2) participating in the life of society, nation, and state, (3) developing positively and democratically, (4) interacting with other nations. In line with the above opinion [3]. States that citizenship education subjects aim for students to have the following abilities: a) think critically, rationally and creatively in responding to issues of citizenship, b) participate actively and responsibly, and act intelligently in community, national and state activities as well as anti-corruption, c) develop critically and democratically to shape themselves based on the characteristics of Indonesian society in order to live together with other nations, d) interact with other nations in world regulation directly or indirectly by utilizing information technology and technology. [13]

Based on the above opinion, the researcher can conclude that the purpose of citizenship education is 1) critical and rational thinking on the issue of citizenship. 2) actively participate in the activities of the nation and state as well as the community and develop democratically and be able to interact with other nations. Furthermore, from these objectives, the researcher classifies them based on student activeness in research observations.

This research was conducted in learning Civics online or in a network. This is because the current condition is still in a state of the Covid-19 pandemic. The learning process carried out online or in a network (online) has advantages and disadvantages. The advantages are saving in transportation and studying anywhere, or the place of learning is flexible, while the disadvantages are sometimes the signal constraints that are not supportive, and the teaching staff is little in the learning process. This learning uses learning tools and media systematically, such as using lesson plan, scenarios, power point, and videos, so that the learning process becomes more organized and enjoyable. It is also necessary to use various learning methods so that the learning process becomes more organized and enjoyable. Students are even more enthusiastic about participating in learning, such as menti.com, which is considered not boring where later students answer the questions provided. The following is a table of observations of 8 times onlines of the learning process in the Civics study program class. 
Table : Observation

\begin{tabular}{|c|c|c|c|c|}
\hline No & Topic & Media & Method & $\begin{array}{c}\text { Character } \\
\text { appear }\end{array}$ \\
\hline 1 & $\begin{array}{l}\text { The } \\
\text { essence, } \\
\text { urgency, } \\
\text { dynamics, } \\
\text { and } \\
\text { challenges } \\
\text { of Civic } \\
\text { Education } \\
\text { and } \\
\text { character } \\
\text { education }\end{array}$ & $\begin{array}{l}\text { Learning } \\
\text { media: } \\
\text { Scenario } \\
\text { s, power } \\
\text { point, } \\
\text { and } \\
\text { Video }\end{array}$ & $\begin{array}{l}\text { Inquiry } \\
\text { learning }\end{array}$ & $\begin{array}{l}\text { Religious, } \\
\text { tolerance, } \\
\text { curiosity, } \\
\text { love the } \\
\text { country } \\
\text { and love } \\
\text { reading, } \\
\text { discipline, } \\
\text { responsibili } \\
\text { ty, } \\
\text { democratic, } \\
\text { independen } \\
\text { t }\end{array}$ \\
\hline 2 & $\begin{array}{l}\text { National } \\
\text { Identity }\end{array}$ & $\begin{array}{l}\text { Learning } \\
\text { media: } \\
\text { Scenario } \\
\text { s, power } \\
\text { point, } \\
\text { and } \\
\text { Video }\end{array}$ & $\begin{array}{l}\text { Problem- } \\
\text { based } \\
\text { Learning }\end{array}$ & $\begin{array}{l}\text { Religious, } \\
\text { tolerance, } \\
\text { curiosity, } \\
\text { love of the } \\
\text { country } \\
\text { and likes } \\
\text { reading, } \\
\text { discipline, } \\
\text { responsibili } \\
\text { ty, } \\
\text { democratic, } \\
\text { independen } \\
\text { t and } \\
\text { creative }\end{array}$ \\
\hline 3. & $\begin{array}{l}\text { National } \\
\text { Integration }\end{array}$ & $\begin{array}{l}\text { Learning } \\
\text { media: } \\
\text { Scenario } \\
\text { s, power } \\
\text { point, } \\
\text { and } \\
\text { Video }\end{array}$ & $\begin{array}{l}\text { Discover } \\
\mathrm{y} \\
\text { learning }\end{array}$ & $\begin{array}{l}\text { Religious, } \\
\text { honesty, } \\
\text { tolerance, } \\
\text { democratic, } \\
\text { curiosity, } \\
\text { love of the } \\
\text { country, } \\
\text { love to } \\
\text { read, } \\
\text { responsibili } \\
\text { ty, love } \\
\text { peace, hard } \\
\text { work, } \\
\text { creative, } \\
\text { independen } \\
\text { t } \\
\text { friendly/co }\end{array}$ \\
\hline
\end{tabular}

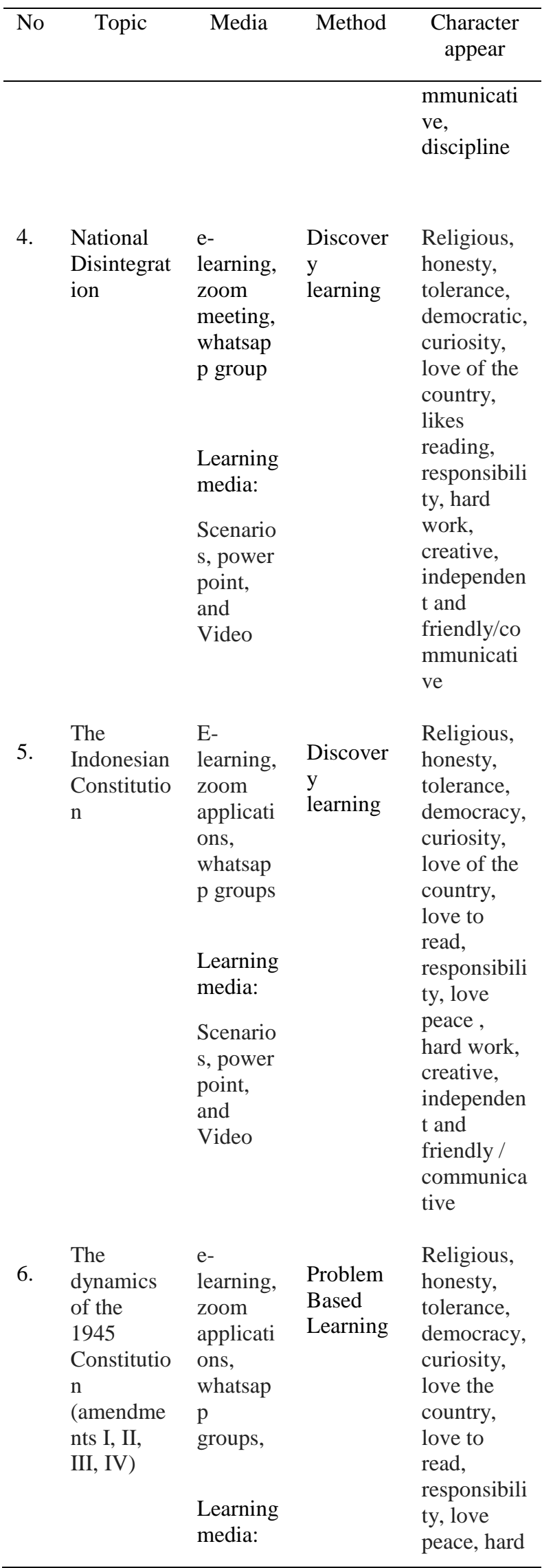




\begin{tabular}{|c|c|c|c|c|}
\hline No & Topic & Media & Method & $\begin{array}{c}\text { Character } \\
\text { appear }\end{array}$ \\
\hline \multirow[t]{2}{*}{7.} & \multirow[t]{2}{*}{$\begin{array}{l}\text { Rights and } \\
\text { Obligation } \\
\text { s of } \\
\text { Citizens }\end{array}$} & $\begin{array}{l}\text { e- } \\
\text { learning, } \\
\text { zoom } \\
\text { applicati } \\
\text { ons, } \\
\text { whatsap } \\
\text { p } \\
\text { groups, }\end{array}$ & $\begin{array}{l}\text { Problem } \\
\text { Based } \\
\text { Learning }\end{array}$ & $\begin{array}{l}\text { work, } \\
\text { creative, } \\
\text { independen } \\
\mathrm{t} \text { and } \\
\text { friendly / } \\
\text { communica } \\
\text { tive } \\
\text { love peace, } \\
\text { work hard, } \\
\text { creative, } \\
\text { independen } \\
\text { t and } \\
\text { friendly / } \\
\text { communica } \\
\text { tive }\end{array}$ \\
\hline & & $\begin{array}{l}\text { Learning } \\
\text { media: } \\
\text { Scenario } \\
\text { s, power } \\
\text { point, } \\
\text { and } \\
\text { Video }\end{array}$ & & \\
\hline 8. & Mid-Test & $\begin{array}{l}\text { Zoom } \\
\text { meeting, } \\
\text { Google } \\
\text { form }\end{array}$ & Test & $\begin{array}{l}\text { hard work, } \\
\text { creative, } \\
\text { independen } \\
t \text { and } \\
\text { friendly / } \\
\text { communica } \\
\text { tive }\end{array}$ \\
\hline
\end{tabular}

The eight online are conducted through the zoom meeting application. The achievement in learning from these four meetings was that students could analyze the case studies presented at each meeting. The material discussed at each meeting refers to the lesson plan Course guide. The learning methods used in learning activities are Discovery Learning and Problem based learning.

At the beginning of each activity, the lecturer brainstormed with the students. Then the lecturer asked one of the students to lead a prayer to start online Civics learning activities today. The lecturer conveyed the learning objectives and continued with the delivery of material through PPT; after delivering the material, the lecturer asked students to provide feedback regarding the material posted on the student's LMS page. The lecturer and the students watched a video presentation related to the material at each meeting, then continued with the lecturer asking students to give comments regarding the video that had been broadcast. Lecturers give appreciation to students who have given their opinions. The lecturer provides information in solving the problem proposed by one of the students. Then the lecturer asks students to discuss today's material. Before the learning process ends, the lecturer asks students to answer the questions provided on menti.com. Today's learning activity ended with the lecturer asking one of the students to read a closing prayer. In the implementation of the eight learning meetings, from the beginning of the lecture, the character values that emerged were religious, tolerance, curiosity, love of the country, and fondness of reading, discipline, responsibility, democracy, and independence. With the increase in lecture meetings and two-way communication intensifying from lecturers and students, at the meeting, the seven-character values that appear to be increased are religious, honesty, tolerance, democratic, curiosity, love for the country, love to read, responsibility, love peace, hard work, creative, independent and friendly/communicative.

The value of religious character in student activities starting learning begins with praying led by student representatives. When they want to ask students to say greetings first, students also say greetings first when they want to answer questions asked by lecturers or other students, and indicators close the learning with prayer.

The character value of honesty that can be proven by the physical presence of students in the virtual class is the Zoom Meeting, even though it is constrained by signal interference during learning, which causes them to be expelled indirectly from the virtual class, but students try to re-enter the Zoom Meeting virtual class. Then there are indicators of expressing opinions according to the actual conditions, which can be proven by students' opinions regarding the two videos that were delivered by linking to the reality that happened.

Tolerance character values such as respecting friends of different religions in the lecture process, respecting friends of different ethnicities or races where students come from many areas from various ethnicities but still respect and respect each other, and treat others equally regardless of religion or differences. Which exists. Then also appears the value of disciplinary character where students enter the virtual classroom not too late even though some are constrained by suddenly missing signals or wrong signals. Orderly indicators follow the rules and obey the rules that have been set.

The value of democratic character, which is marked by not imposing the will on others, can be seen from not imposing their will or opinion on others, students respecting the opinions and rights of other friends when friends express opinions, respect these and also try to respect the opinions of their friends who are different from themselves. A friend's opinion that is different from himself is respected without feeling his opinion is the most correct.

Curiosity character values also appear, such as students' ability to trace information sources first, then the indicator focuses on statements such as that made by a student who asks why demographics can be a factor causing disintegration. Students have also read material that has been sent on LMS. Elearning unsri.co.id, overall students, are enthusiastic in participating in learning, then asking lecturers or friends about what is unknown about learning, 
such as a student who asked the lecturer about the material he did not understand.

\section{CONCLUSION}

Based on the results, it can be concluded that students' character values continue to increase in each meeting. It can be seen from the beginning of the lecture that the character values that emerge are religion, tolerance, curiosity, love of the country and love to read, discipline, responsibility, democratic, and independent, then with the increase in lecture meetings and intense two-way communication between lecturers and Students then found at the meeting of the seven character values that appeared to be increased, namely religious, honesty, tolerance, democratic, curiosity, love of the country, fond of reading, responsibility, love of peace, hard work, creative, independent and friendly or communicative.

\section{ACKNOWLEDGMENT}

The research/publication of this article was funded by DIPA of Public Service Agency of Universitas Sriwijaya 2020 SP. DIPA-023.17.2.677515/2020, revision 01. On March, 16 2020. In accordance with the Rector's Decree Number: 0685/UN9/SK.BUK.KP/2020. On July 15, 2020.

\section{REFERENCES}

[1] Agustini. (2014). Pendidikan Karakter KonstruksiTeori dan Praktik. Jogjakarta: Ar-ruzz Media.

[2] Ari, Jaya, Ida bagus. (2013). Pendidikan Karakter Berbasis Nilai dan Etika di Sekolah. Jogjakarta: Ar-ruzz Media.

[3] Budimansyah, D. (2008) Pendidikan Kesadaran Kewarganegaraan Multimensional. Bandung: Genesindo.

[4] Chotimah, Umi dan Nurdiansyah, Edwin. (2017). Meningkatkan High Order Thinking Skills Mahasiswa Semester III PPKn dalam Pembelajaran Psikologi Sosial melalui Penerapan Metode Six Thinking Hats. Jurnal Civics Volume 14 Nomor 1, Mei 2017.

[5] Chotimah, Umi, Aisyah, Nyimas. Meryan Sumayeka (2019). Analisis Nilai Karakter Siswa Dalam Pembelajaran Berbasis HOTS dan Berbantuan Media ICT di Sekolah Menengah (Studi Kasus Pada Pembelajaran PPKn dan Matematika). Laporan Penelitian Hibah Kompetitif, Tahun 2019.

[6] David Geary, Daniel Bearch, Robert Ochsendorf, Katleen Maan Koeepe. (2016). Matchematics Higher Order Thingking Skills. [Internet]. Tersedia di: hhtps://faculty.missouri.edu/ gearyd.com. Diakses pada tanggal 16 Oktober 2020.
[7] Fadhil. (2019). Pendidikan Karakter disatuan Pendidikan.Jurnal Pendidikan dan Kebudayaan, Vol. 17 No.5 Sep.

[8] Firdaus Syam, (2015). Pentingnya Pembangunan Karakter. [Internet]. Tersedia di: https://republika.co.id/berita/nli0t327/pentingnyapembangunan-karakter-di-perguruan-tinggi. Diakses pada tanggal 16 Oktober 2020.

[9] Gloria, Vitrail. (2018). Pancasila dan Kewarganegaraan. [Internet]. Tersedia di : http://repository.uinsu.ac.id/2466/1/ISI PANCASILA U SIONO.pdf. Diakses pada tanggal 16 Oktober 2020.

[10] Komara,Endang. (2017). Curriculum and Civic Education Teaching in Indonesia. Jurnal Internasional Untuk Pendidikan. 10 (1), Hlm.23-

[11] Mendikbud. (2017). Peraturan Presiden Nomor 87 tahun 2017 tentang Penguatan Pendidikan Karakter. [Internet]. Tersedia di:

https://jdih.kemdikbud.go.id/arsip/Permendikbud_Tahu n2018_Nomor20.pdf. Diakses pada tanggal 16 Oktober 2020 .

[12] Maulana, Datuk Haris. (2019). Cekcok Masalah Spanduk, 2 Kelompok Mahasiswa USU Saling Serang. [Internet]. Tersedia di: https://news.detik.com/berita/d4806794/,cekcok-masalah-spanduk-2-kelompokmahasiswa-usu-saling-serang?. Diakses pada tanggal 16 Oktober 2020.

[13] Priyanto, A.T Sugeng dkk. (2008). Pendidikan Kewarganegaraan. Jakarta: Pusat Perbukuan Departemen Pendidikan Nasional.

[14] Ristekdiki. (2015). Permenristekdikti No.44 tahun 2015 tentang Standar nasional Pendidikan. [Internet]. Tersedia di: https://img.akademik.ugm.ac.id/unduh/2015/PERMEN RISTEKDIKTI_Nomor_44_Tahun_2015_SNPT.pdf. Diakses pada tanggal 16 Oktober 2020.

[15] Sarbani, Harpani Matnuh, Fatimah. (2013). Pendidikan Kewarganegaraan.

https://ppjp.ulm.ac.id/journal/index.php/pkn/issue/view/ 164.pdf . Diakses pada tanggal 16 Oktober 2020.

[16] Siswanarti. 2017. Pentingnya Pendidikan Karakter Untuk Mahasiswa. Bandung: Remaja Rosdakarya.

[17] Warsito, Budi. (2019). Mahasiswa Tewas Akibat Tawuran, Universitas Nommensen: Pelaku Dipecat. [Internet]. Tersedia di: https://news.detik.com/berita/d4795174/1-mahasiswa-tewas-akibat-tawuranuniversitas-nommensen-pelaku-harus-dipecat?. Diakses pada tanggal 16 Oktober 2020. 